\title{
Water Policy \\ Exploring water indices and associated parameters: a case study approach --Manuscript Draft--
}

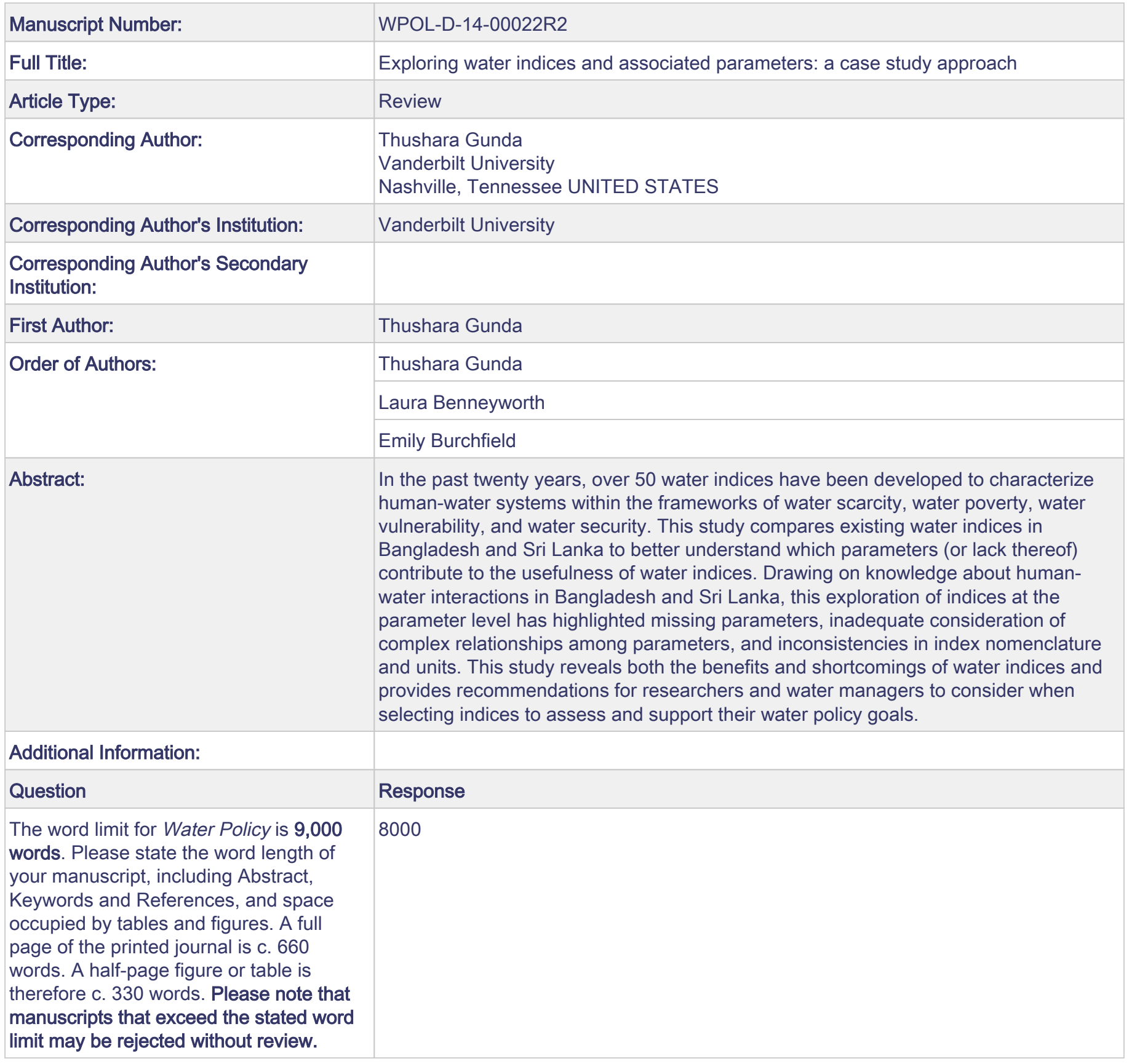


Title: Exploring water indices and associated parameters: a case study approach

\title{
Authors: Thushara Gunda ${ }^{\mathrm{a}}$, Laura Benneyworth ${ }^{\mathrm{b}}$, Emily Burchfield $^{\mathrm{c}}$
}

\author{
${ }^{\mathrm{a} C}$ Corresponding author: Vanderbilt Institute for Energy and Environment and Department of \\ Civil and Environmental Engineering, Vanderbilt University, Nashville, TN 37240-7702, USA. \\ Email: thushara.gunda@ vanderbilt.edu. \\ ${ }^{\mathrm{b}}$ Vanderbilt Center for Environmental Management Studies, Vanderbilt University, Nashville, \\ TN, USA. Email: laura.m.benneyworth@ vanderbilt.edu \\ ${ }^{\mathrm{c}}$ Vanderbilt Institute for Energy and Environment and Vanderbilt Center for Environmental \\ Management Studies, Vanderbilt University, Nashville, TN, USA. Email: \\ emily.k.burchfield@vanderbilt.edu
}

\begin{abstract}
In the past twenty years, over 50 water indices have been developed to characterize human-water systems within the frameworks of water scarcity, water poverty, water vulnerability, and water security. This study compares existing water indices in Bangladesh and Sri Lanka to better understand which parameters (or lack thereof) contribute to the usefulness of water indices. Drawing on knowledge about human-water interactions in Bangladesh and Sri Lanka, this exploration of indices at the parameter level has highlighted missing parameters, inadequate consideration of complex relationships among parameters, and inconsistencies in index nomenclature and units. This study reveals both the benefits and shortcomings of water indices and provides recommendations for researchers and water managers to consider when selecting indices to assess and support their water policy goals.
\end{abstract}


Keywords: Water scarcity, water poverty, water security, water vulnerability, water indices, Bangladesh, Sri Lanka 


\section{Introduction}

In the past century, rates of water usage have grown twice as rapidly as global population (FAO, 2007; UN, 2013a). Although global renewable freshwater resources are currently sufficient to meet population requirements, uneven distribution of water resources, compounded by pollution and mismanagement, results in severe national and regional disparities in water availability and quality (UN, 2013a). Considering the influence of human management on the distribution of water resources, it is important to study both the physical and human aspects to develop a comprehensive understanding of water systems (hereafter referred to as "human-water systems").

Human-water systems were initially viewed through the lens of "water scarcity," which assessed the amount of water physically available to a nation (Falkenmark, 1989). However, this traditional definition of water scarcity gives no consideration to the capacity of a nation to adjust to limited water resources (Appelgren \& Klohn, 1999). Consequently, the framework expanded to "water poverty," which assesses both the physical and economic capabilities of a nation to meet its water needs. External threats to the human-water system (e.g., extreme weather events) were incorporated into the framework through "water vulnerability." Most recently, interactions between humans and water have been viewed comprehensively in terms of "water security." UNWater defines water security as "the capacity of a population to safeguard sustainable access to adequate quantities of acceptable quality water for sustaining livelihoods, human well-being, and socio-economic development, for ensuring protection against water-borne pollution and waterrelated disasters, and for preserving ecosystems in a climate of peace and political stability" (UN-Water, 2013, p. 1). 


\section{Methods}

In this study, an "index" is computed from multiple parameters and a "parameter" is defined as a value that is measured or observed. Some parameters are also computed using multiple values; additional information regarding these parameters is presented in the following sections. The various parameters relate to different aspects of water resources issues. For example, river flows and groundwater volumes can be taken as measures of water availability 
whereas availability of piped water and proximity of households to wells can be taken as measures of access. We group like parameters together and refer to the groups as "components."

\subsection{Index Descriptions}

Multiple water indices in the current literature were reviewed. Only national indices for Sri Lanka and Bangladesh that have already been developed or could be developed given readily available information were included in the analysis (for descriptions of the two countries, see Appendix). Indices were grouped under frameworks based primarily on their nomenclature. The indices included in this study are: the Falkenmark Indicator (Falkenmark, 1989), Social Water Scarcity Index (Appelgren \& Klohn, 1999), Water Poverty Index (Lawrence, Meigh, \& Sullivan, 2002), Rural Water Livelihoods Index (Sullivan et al., 2009), Index of Drinking Water Adequacy-2 (Kallidaikurichi \& Rao, 2009), National Water Security Index (ADB, 2013a), Water Security Index (Lautze \& Manthrithilake, 2012), Water Resources Vulnerability Index (Raskin et al., 1997), and Composite Water Vulnerability Index (Paladini, 2012).

\section{Water Scarcity}

The Falkenmark Indicator identifies regions as being under "water stress" when less than 1,700 cubic meters $\left(\mathrm{m}^{3}\right)$ of water are available per capita per year; regions are "water scarce" when only $1,000 \mathrm{~m}^{3}$ of water is available per capita per year (Falkenmark, 1989). The Falkenmark Indicator is unique because it is an index containing only a single parameter; the index is defined simply as water resources per capita. This traditional definition of water scarcity is based on physical resources (i.e., total water resources available to a country and its population size) and gives no consideration to the societal response capacity of a nation to adjust the scarcity situation. In response to these criticisms, Appelgren \& Klohn (1999) attempted to account for this societal capacity by dividing the Falkenmark Indicator by the Human Development Index 
(HDI), a composite index that is composed of national parameters for education, health, and income (UNDP, 2013a). They argued that this new index, called the Social Water Scarcity Index, reflected the social and institutional capacity of a country to respond to water stress.

\section{Water Poverty}

"Water poverty" links physical estimates of water availability to socioeconomic variables that reflect conditions of poverty (Lawrence, Meigh, \& Sullivan, 2002; Sullivan, 2002; Feitelson \& Chenoweth, 2002; Sullivan \& Meigh, 2003; Sullivan et al., 2003). Water poverty indices account for the fact that many countries with adequate physical water resources lack the political and financial resources necessary to make these resources available (Seckler et al., 1998; Rijsberman, 2006; Molden, 2007; Molle \& Mollinga, 2003). The most commonly used index in this framework is the Water Poverty Index. This index includes five components of water poverty: resources, access, capacity, use, and environment (Lawrence, Meigh, \& Sullivan, 2002; Sullivan, 2002). The Water Poverty Index encompasses not only water and income parameters but also parameters regarding ecosystem productivity and human health (Lawrence, Meigh, \& Sullivan, 2002; Sullivan, 2002; Brown \& Matlock, 2011).

In 2009, Sullivan et al. (2009) introduced a version of the Water Poverty Index for rural communities called the Rural Water Livelihoods Index, which distinguishes between urban and rural human-water systems. The Rural Water Livelihoods Index includes components accounting for access to water and sanitation, crop and livestock water security, clean and healthy environments, as well as secure and equitable water entitlements. This index also utilizes parameters measuring local corruption, agricultural holdings, and water quality (total nitrogen consumed on cultivated land) (Sullivan et al., 2009). 
Biswas \& Seetharam (2008) simplified the WPI to create an Index of Drinking Water Adequacy (IDWA). The first version of IDWA, IDWA-1, is an aggregate of internal renewable fresh water resources, access to improved water sources, national capacity to purchase water (represented by nominal gross domestic product), domestic water use, and water quality (represented by diarrheal deaths) parameters. Kallidaikurichi \& Rao (2009) updated this index and created the Index of Drinking Water Adequacy- 2 by changing access from all improved water sources to only households with piped connections. The authors argued that the revised access parameter accounted for opportunity costs of time lost collecting water (Kallidaikurichi \& Rao, 2009).

\section{Water Vulnerability}

Vulnerability is broadly defined by Kelly \& Adger (2000) as "the ability or inability of individuals and social groupings to respond to, in the sense of cope with, recover from or adapt to, any external stress placed on their livelihoods and well-being" (Kelly \& Adger, 2000, p. 328). External stresses on water systems include natural hazards such as floods, droughts, and storm surges as well as runoff changes from climate change (Gain, Giupponi, \& Renaud, 2012).

Raskin et al. (1997) developed the Water Resources Vulnerability Index (WRVI), which is based on water supply and storage parameters, a withdrawal to discharge ratio, and a coping capacity index reflecting the nominal GDP per capita. The WRVI has two variations: WRVI-1 is a composite value of the index components while WRVI-2 is equal to the worst value for any one of the components. Because the components are weighed equally, only WRVI-1, henceforth referred to as WRVI, is considered in the rest of this paper. The Composite Water Vulnerability Index, developed by Paladini (2012), has four components: industrial growth rate, level of development, water stress, and water availability. GDP per capita, domestic and industrial water 
use, electricity production, HDI, and population density are some of the parameters included in this index (Paladini, 2012).

\section{Water Security}

Lautze \& Manthrithilake (2012) developed a Water Security Index for 46 countries in Asia that includes five components: basic household needs, food production, environmental flows, risk management, and water independence. They concluded that the Water Security Index was strongly correlated with the economic development of the 46 nations they studied. The Asian Development Bank's National Water Security Index also has five components: household water security, urban water security, environmental water security, economic water security, and resilience to water-related disasters (ADB, 2013a). Despite the inclusiveness of this framework, water security indices rarely account for seasonal water-related shocks.

\subsection{Parameter and Component Descriptions}

A comprehensive list of parameters comprising the indices listed above was compiled. Following Lawrence, Meigh, \& Sullivan (2002), the parameters were organized into five components: resources, access, use, capacity, and environment. Where appropriate, the results and tables are organized using these component classifications. The resource component represents the amount of water physically available to a region. The access component represents accessibility to improved water and sanitation resources within one kilometer. Improved water sources include household connections, public standpipes, boreholes, protected dug wells, protected springs, and rainwater collection; improved sanitation facilities include connection to a public sewer, septic system, pour-flush latrine, simple pit latrine, or a ventilated improved pit latrine (WHO \& UNICEF, 2012). 
The water use component represents the amount of water used in the nation, either in sum or partitioned across different sectors (e.g., agricultural, domestic, and industrial). "Water use" can refer to either water withdrawal or water consumption; a portion of withdrawn water is returned to a water source, while consumed water is lost to mechanisms such as evaporation and is thus no longer available to meet human or environmental needs. The capacity component is divided into two subcomponents: soft capacity and hard capacity. Soft capacity refers to nonengineered solutions to water management such as education and institutional capacity, while hard capacity refers to built infrastructure such as dams and wastewater treatment plants (Brown \& Lall, 2006; Gleick, 2003). The environment component represents the interactions between water resources and the ecosystem, which plays a significant role in protecting the quality and quantity of water.

\subsection{Overview of Analysis}

Water indices for Bangladesh and Sri Lanka were compared to determine the relative rankings of these countries. The Falkenmark Indicator and the Social Water Scarcity Index for Bangladesh and Sri Lanka were calculated based on the most recent Food and Agriculture Organization (FAO) and UN Development Programme data (FAO, 2013; UNDP, 2013a). The remaining indices were compiled from the original publications. Although the data used to develop indices are from different years, it is assumed that the relative placement of Bangladesh and Sri Lanka has not changed over time.

After compiling a comprehensive list of parameters comprising the water indices, the parameters were organized into the five components. When possible, the most recent parameter values were obtained from FAO and other resources. Otherwise, original publication data was used. Drawing on knowledge about human-water interactions in Bangladesh and Sri Lanka, 
missing parameters as well as inconsistencies in the quantification of included parameters were identified within each of these components. Information is noted when there is no readily available information for missing parameters.

\section{Results}

\subsection{Indices}

Water indices for Bangladesh and Sri Lanka have been shaded in Table 2 to indicate the country with a more favorable ranking. Bangladesh has more physical water resources than Sri Lanka at the national level (i.e., Falkenmark Indicator and Social Water Scarcity Index). Water poverty indices (i.e., Water Poverty Index, Rural Water Livelihoods Index, and Index of Drinking Water Adequacy-2) suggest that Sri Lanka's political and financial resources are sufficient to compensate for its fewer physical water resources. The water vulnerability indices give a mixed message; the Water Resources Vulnerability Index suggests that Sri Lanka is more stressed, while the Composite Water Vulnerability Index suggests that Sri Lanka is more resilient. Overall, however, Sri Lanka ranks more favorably in water security indices (i.e., National Water Security Index and Water Security Index) than Bangladesh.

\subsection{Parameter Values}

Resource parameters include long-term annual water resource averages (either total or based on source of water (i.e., within or outside country borders)), a measure of the inter-annual variability in precipitation, and extreme weather indicators. Although Bangladesh has more total water per capita than Sri Lanka, Sri Lanka has more internal water resources per capita than Bangladesh, due to Sri Lanka's lack of dependence on external sources (Table 3). As measured by the coefficient of variation in precipitation, inter-annual variability in precipitation is greater 

more prone than Sri Lanka to floods, windstorms, droughts, and storm surges (ADB, 2013a). Neither the Water Resources Vulnerability Index nor the Composite Water Vulnerability Index contained any parameters measuring extreme weather.

Access parameters measure the percentage of the population with access to improved water sources (either total or only as household connections) and sanitation. Some of the indices also distinguished between access parameters for urban and rural populations. Each country's urban population has greater access to water than its rural population. Bangladeshi urban and rural populations have equal access to sanitation while Sri Lanka's rural population has higher access to sanitation than the country's urban population. Sri Lanka's urban and rural populations each have greater access to improved water sources and sanitation than the corresponding Bangladeshi populations (Table 3).

Most indices in Table 2 include water withdrawal values, although some of the parameters are labeled generally as "use" (Table 3). The indices listed in Table 2 quantify water withdrawals as either a volumetric measurement per capita or as a percentage of total renewable water resources; because normalized data better reflect quality-of-life, all data presented in Table 3 have been normalized by total water resources. Some indices consider total withdrawal values while others prioritize certain sectors over others. For example, Index of Drinking Water Adequacy-2 prioritizes domestic use by focusing specifically on drinking water while the Water Security Index only considers agricultural use of water. The Composite Water Vulnerability Index includes volumetric inputs for both total withdrawals and water use by the industrial and domestic sectors, but does not consider agricultural use (Paladini, 2012). Of the indices listed in Table 2, only the Water Poverty Index explicitly includes a water consumption parameter that 
captures the percentage of a country's land that is under severe water stress (i.e., where the water consumption is greater than $40 \%$ of its available water) (Lawrence, Meigh, \& Sullivan, 2002; YCELP \& CIESIN, 2005). A greater amount of water is being withdrawn (both per capita and as a percentage of total available water) in Sri Lanka than in Bangladesh in each of the three sectors (Table 3). Because most agricultural water use is consumptive (Vaux, 2012), a higher proportion of Sri Lankan land is stressed than Bangladeshi land (YCELP \& CIESIN, 2005).

Soft capacity parameters include metrics of national education, health, income, and corruption. Education, health, and income parameters are commonly used to assess the level of a nation's development. The HDI is a composite index commonly used as a measure of a nation's soft capacity. Some of the water indices include HDI as a parameter (e.g., Social Water Scarcity Index) while others explicitly include individual metrics for education, health, and income. The Water Poverty Index, for example, uses HDI parameters for education and income, but replaces the health parameter of life expectancy with child mortality rate because the authors argue that the latter is more closely related to access to clean water (Lawrence, Meigh, \& Sullivan, 2002). Sri Lankans are more educated than Bangladeshis, both in terms of years of schooling and literacy rate. Sri Lankans are also healthier on average, with a greater life expectancy at birth and a lower child mortality rate. Bangladesh has a lower percentage of undernourished people than Sri Lanka. Sri Lanka has higher income per capita (both GNI and GDP) and a higher GDP growth rate. However, Sri Lanka also has a higher GINI coefficient, indicating greater inequality in income distribution within the country. Corruption was only addressed by one index evaluated, the Rural Water Livelihoods Index. The corruption perception parameter used in this index suggests that Sri Lanka is significantly less corrupt than Bangladesh. Overall, Sri Lanka has higher soft capacity than Bangladesh (Table 3). 
In the indices reviewed, hard capacity is seldom evaluated but has been operationalized as the presence of major infrastructure, such as large reservoirs and wastewater treatment plants. Both Bangladesh and Sri Lanka have approximately the same amount of large storage capacity (Table 3). The Water Security Index includes a risk management parameter that measures the extent to which countries are buffered from rainfall variability (as measured by the coefficient of variation of precipitation) through large dam storage (Lautze \& Manthrithilake, 2012); nations with higher inter- and intra-annual variability in rainfall require more infrastructure than nations with little variability in rainfall. Because Sri Lanka's higher inter-annual variability is balanced by its greater upstream storage capacity (Table 3), both Bangladesh and Sri Lanka received the same value for the risk management parameter in the Water Security Index (Lautze \& Manthrithilake, 2012). In addition, Sri Lanka currently treats more of its wastewater than Bangladesh (ADB, 2013a).

Ecosystems are extremely complex and are not often addressed in water indices. When ecosystems are considered, they are often assessed using proxies such as environmental flows and land cover. The indices reviewed include few consistent parameters that address the environment. Parameters grouped under the environment component are either water-specific or general measures of ecosystem health. Environmental flows, or the amount of water unclaimed for human use and thus available to ecosystems, are greater in Bangladesh than Sri Lanka (Table 3). Water quality impacts are measured with either human health or chemical pollution indicators. A common human health indicator is the prevalence of "waterborne" diarrheal diseases; Bangladesh has more diarrheal incidents per 100,000 people than Sri Lanka (ADB, 2013b). Chemical pollution indicators are either agriculture-specific (i.e., Water Poverty Index) or industry-specific (i.e., Composite Water Vulnerability Index). Sri Lanka consumes more 
fertilizers and pesticides per hectare of arable land than does Bangladesh. Biochemical oxygen demand (BOD), a related metric to dissolved oxygen, reflects the amount of dissolved oxygen needed by aerobic organisms to break down organic material in water (Penn, Pauer, \& Mihelcic, 2006); Bangladesh has a much higher industrial BOD than Sri Lanka (Paladini, 2012).

Biodiversity and a composite River Health Indicator are the two general measures of ecosystem health included in the Water Poverty Index and the National Water Security Index, respectively. Biodiversity is measured as the percentage of threatened mammals and birds in the country; biodiversity is greater in Sri Lanka than Bangladesh (Lawrence, Meigh, \& Sullivan, 2002; YCELP \& CIESIN, 2005). The River Health Indicator values in the National Water Security Index were developed using GIS tools to measure pressures and threats to river systems from watershed disturbance and pollution activities (such as livestock density) and the vulnerability of the river systems to alterations in natural flows by infrastructure development and biological factors (such as river network fragmentation and nonnative species) (ADB, 2013a). Although information regarding soil salinization and nonnative species were not provided, the Asian Development Bank reports that both countries' rivers are very poor in health with Sri Lanka's rivers being marginally healthier than Bangladesh's rivers (ADB, 2013a).

\subsection{Missing Parameters}

During the analysis, numerous missing parameters that could contribute to a comprehensive understanding of the human-water systems of Bangladesh and Sri Lanka were identified (Table 4). Parameters for total, internal, and external water resources are based on long-term annual averages, which may mask seasonal variations in water availability (Brown \& Lall, 2006; Rijsberman, 2006). Due to their monsoonal climate, Bangladesh and Sri Lanka both experience high intra-annual variability in rainfall (Brown \& Lall, 2006), which is not accounted 
for in any of the indices listed in Table 2. Additionally, none of the indices contained any information regarding the distribution of water resources among surface and groundwater resources. The distinction between surface and groundwater sources in quantifying water resources is critical since the two resources have significantly different recharge rates (Hornberger et al., 1998). Sri Lanka has more groundwater per capita than Bangladesh (FAO, 2013). While groundwater usage information is available for Bangladesh, no such information for Sri Lanka is available (Table 4). Villholth \& Rajasooriyar (2010) approximate that $60 \%$ of Sri Lanka's total population is currently dependent on groundwater for domestic use.

Although the indices presented in Table 2 include valuable access information (such as distinctions between urban and rural populations), parameters of other intra-group differences were excluded, notably between men and women. Women have been shown to be disproportionally affected by lack of water access because they are predominantly responsible for household water collection, especially in poor households (UNDP, 2006; Sultana, 2007; Sullivan et al., 2009). Men and women fare more equally in Sri Lanka than in Bangladesh (Table 4; Gender Inequality Index values closer to zero indicate men and women fare equally).

Kaufmann (2005) identifies six key aspects of governance: voice and accountability, political stability, government effectiveness, regulatory quality, rule of law, and control of corruption. Of these parameters, only corruption has been included in one of the index calculations. According to the World Bank's 2012 Worldwide Governance Indicators, Sri Lanka's government is more stable and effective, and has a greater ability to formulate and implement sound policies, than Bangladesh's government, but the latter's population ranks higher for voice and accountability (World Bank, 2013a). 
Dams are not the only built infrastructure present in Bangladesh and Sri Lanka. Both reservoirs and tanks play a large role in stabilizing food production in Sri Lanka (see Appendix for additional details). Tanks cover almost $25 \%$ of the total surface water storage area in the country (Mawilmada et al., 2010). Similarly, small-scale surface irrigation schemes account for $16 \%$ of national irrigation coverage in Bangladesh (FAO, 2012).

While nutrient pollution is relevant for both countries, none of the indices include metrics for water quality issues of significant concern in Bangladesh and Sri Lanka such as toxic metal pollution, fecal coliforms, and salinization. Additionally, although deforestation, including the conversion of forests to agricultural land, continues to threaten Asia, no information on forest cover or the amount of protected land has been incorporated into any of the indices. Currently, a higher percentage of Sri Lanka's lands are covered by forests, and more Sri Lankan lands are protected than Bangladeshi lands (ADB, 2013c; WRI, 2013). Annual deforestation rates, however, are higher in Sri Lanka than in Bangladesh (ADB, 2013b).

\section{Discussion}

While water indices can facilitate program evaluation and serve as tools for water managers, as stated in Section 3.1, the findings from water indices can be ambiguous. Unlike parameter level comparisons, index level comparisons offer limited insight at small geographic scales. Our parameter level analysis has shown specific metrics (e.g., education and income) that contribute to Sri Lanka's improved indices. Water index parameters, however, have limitations as outlined below.

The most notable issue uncovered during the analysis was the absence of key parameters that could greatly impact overall water indices (Table 4). While no single index can capture all of 
the complex interactions implicit in human-water systems, the omission or inclusion of key parameters can alter the conclusions drawn from an index (Grey \& Sadoff, 2007). For example, parts of both Bangladesh's and Sri Lanka's populations rely predominantly on groundwater resources, which has resulted in aquifer depletion in both countries (Shah et al., 2003; Brown \& Lall, 2006; Senaratne, 1996; ADB, 2013a). Furthermore, declining groundwater levels in Bangladesh are affecting water quality, causing adverse effects to soils and limiting crop growth (FAO, 2012). However, groundwater resource or usage data for both countries are glaringly absent from all evaluated indices. This absence is in part due to lack of available information, so policymakers and water managers should ensure that groundwater resource and usage data are being collected to help develop a comprehensive understanding of the current state of their water resources.

Similarly absent in the indices are water-specific information regarding capacity and water quality parameters. It should be noted that while general governance information is valuable, it gives little insight into the specific structure and management of water infrastructure. The general World Bank Governance Indicator for government effectiveness, for example, does not seem to adequately represent the concerns arising from limited coordination between Sri Lanka's water agencies (for additional details, see Appendix: Country Descriptions). Education metrics (e.g., literacy rate) also provide little information regarding awareness of basic hydrological concepts such as the water cycle and how to limit contamination of water supplies. Future research should assess how information on water-specific governance and education can be collected and measured. While not a comprehensive list, Table 4 lists additional parameters that should be evaluated for inclusion in water indices. Until this data becomes available, the rationale for using certain proxies should be explicitly stated in analyses. 
Few of the evaluated indices considered the complex relationships between the components. The Water Security Index was one of the few indices to include a risk management parameter to measure the extent to which a nation was buffered from rainfall variability through large dam storage. Similarly, the presence of water agreements with neighboring countries suggests that a country's external water resources should not be ignored. Most of the evaluated indices, however, give equal weight to the parameters listed in Table 3, rather than examining these complex relationships when developing indices. Since the indices typically have more parameters reflecting social conditions than physical conditions, Sri Lanka has more favorable water indices despite having a third of Bangladesh's total water resources available per capita (Tables 2 and 3). Equal weighting of all parameters also causes valuable information to be lost. For example, in addition to having greater income per capita, Sri Lanka also has higher income inequality (as indicated by the GINI coefficient and percentage of undernourished people) than Bangladesh.

The indices evaluated did not always reflect the framework implied in their nomenclature. For example, the Water Resources Vulnerability Index has no parameters measuring natural hazards but the National Water Security Index does. In addition, the Water Poverty Index includes parameters measuring agricultural water quality, which are not present in any other indices. Inconsistencies in parameter units were also present. For example, some of the indices only use per capita volumetric measurements, while the percentage of water used relative to total water resources is a better indicator of the stress on a nation's water resources. Some indices also had issues with double counting; the Composite Water Vulnerability Index, for example, had a parameter representing total water use as well as additional parameters for water use by the industrial and domestic sectors (Paladini, 2012). 


\section{Conclusion}

This analysis demonstrates that policy makers, water managers, and academics should use water indices with caution. Human-water systems are extremely complex, and all of their parameters cannot be encompassed by any one index. Therefore, researchers and water managers should be cautious when selecting and applying an index to monitor progress towards their national goals. Particular attention should be given to the selection of parameters relevant to national priorities. When possible, parameters that reflect complex hydrological characteristics and contain water-specific metrics should be used. Regardless of the shortcomings outlined here, water indices are a valuable method to integrate physical and social factors influencing humanwater systems. Following these recommendations will improve the likelihood of these indices providing a comprehensive representation of the most critical aspects of a nation's water resource issues.

Acknowledgements: This material is based upon work supported by the Office of Naval Research through Grant No N00014-11-1-0683 and the National Science Foundation Graduate Research Fellowship Program under Grant No DGE-0909667 and by WSC program Grant No NSF-EAR 1204685. We would like to thank George Hornberger and Jonathan Gilligan for their feedback. 


\section{Appendix: Country Descriptions}

\section{Bangladesh}

Bangladesh, a least developed country, is one of the most densely populated countries in the world (Table 1) (UNCTAD, 2011; FAO, 2012). Bangladesh is a riverine country with 7\% of the total country's land area covered by rivers, notably the Ganges, Brahmaputra, and Meghna (FAO, 2012). More than $90 \%$ of Bangladesh's surface water originates in other countries (Chowdhury, 2010). The majority of rain falls during the annual monsoon, from June to September, when $80 \%$ of annual precipitation occurs (Chowdhury, 2010). The country receives an annual average of 2,320 millimeters $(\mathrm{mm})$ of rain but there is significant spatial variation in the amount of rainfall received, with an annual average of $1,110 \mathrm{~mm}$ of rainfall in the west to over 5,000 $\mathrm{mm}$ in the northeast (FAO, 2012; FAO, 2013). Water is the primary transportation medium and water-intensive industries such as agriculture, fisheries, forestry, and aquaculture are significant contributors to Bangladesh's economy. Currently, groundwater is the primary water source in Bangladesh, comprising 79\% of total water use in 2008 (FAO, 2012). The agricultural sector, particularly paddy cultivation, is the biggest water user, accounting for $88 \%$ of the country's total water withdrawals in 2008 (Chowdhury, 2010; FAO, 2013).

Bangladesh is extremely vulnerable to frequent floods, cyclones, droughts, and storm surges. Due to its flat and low-lying topography, sea level rise is also of concern (Chowdhury, 2010). Although the country has plentiful water during the monsoon season, there is insufficient storage throughout the country to meet the needs of people and agriculture during the dry season (FAO, 2012). Furthermore, water quality has been adversely impacted by agricultural runoff, fecal contamination due to inadequate sanitation, saltwater intrusion, and pollution from industrial sources. To address contamination of surface waters, in the 1970s, the Bangladesh 
government initiated a nationwide program to provide shallow groundwater tube wells to many rural residents. This provided a dependable alternative drinking water supply until arsenic contamination was discovered in 1994 (Biswas \& Adank, 2004). Today, an estimated one million tube wells are contaminated with arsenic, exposing over 30 million people to its toxic effects (Chowdhury, 2010; FAO, 2013). Increased salinity in surface waters has occurred because of decreased flows, and saltwater intrusion in the coastal areas is evident in groundwater drinking wells (Chowdhury, 2010; FAO, 2013).

In Bangladesh, the Ministry of Water Resources (MoWR) is responsible for planning, implementation, and operation of all water resource activities in Bangladesh. Two of the major institutions under MoWR are the Bangladesh Water Development Board (BWDB) and the Water Resources Planning Organization (WARPO). WARPO has national and regional water planning responsibilities, and BWDB is charged with the execution of over 400 water projects. The National Water Resources Council (NWRC) is the national body responsible for water policy in Bangladesh. WARPO has a mandate to coordinate with all relevant ministries through the NWRC (Chowdhury, 2010). Delivery of water and sewerage services in the larger cities is the responsibility of the Water and Sanitation Authorities, whereas local governments implement water supply projects in smaller municipalities. The Department of Public Health Engineering is the national agency responsible for water and sanitation facilities in rural areas (Chowdhury, 2010). Nongovernment organizations are primarily responsible for implementing or extending water service in the country, either directly or indirectly through microfinance assistance (Biswas \& Adank, 2004). Bangladesh has reached an agreement with India regarding equitable use of the Ganges in 1996, but no such agreements have been made for the other transborder rivers (FAO, 2012). Water rights in the country are linked to land ownership rights, but over $45 \%$ of the rural 
population in the country is either landless or "functionally landless," owning less than 200 square meters of land (World Bank, 2013).

\section{Sri Lanka}

Sri Lanka, an island nation, is divided into three climatic zones determined by rainfall patterns: the wet zone, the intermediate zone, and the dry zone. Sri Lanka receives rain from two monsoons, the northeast monsoon and the southwest monsoon. The wet zone receives rain during both the northeast and southwest monsoon, while the dry zone, which covers threequarters of the island, receives rain only during the northeast monsoon. Like Bangladesh, there is high spatial variation in the rainfall patterns, with an average annual rainfall of less than 1,000 $\mathrm{mm}$ in the northwest and over 5,000 $\mathrm{mm}$ in the central highlands of the country (Gunatilaka, 2008). Both floods and droughts are issues of particular concern in parts of the island (FAO, 2012). Because Sri Lanka is an island nation, it has no transborder water resources. Water quality issues include agricultural pollution, fecal contamination, and saltwater intrusion, notably in the coastal areas (Villholth \& Rajasooriyar, 2010).

As in Bangladesh, agriculture (predominantly paddy cultivation) plays a large role in the local Sri Lankan economy. In Sri Lanka, irrigation schemes are classified as minor, medium, and major depending on the size of the area that can be irrigated by the scheme. Small artificial lakes and ponds, known locally as tanks, dominate the minor irrigation systems (Marambe, Pushpakumara, \& Silva, 2012). Due to overcrowding in other parts of the country, the Sri Lankan government initiated the Mahaweli Development Programme in the 1970s which oversaw the construction of medium and major irrigation systems in the dry zone.

There are approximately 40 institutions and 40 legislative acts related to water in Sri Lanka (Manthrithilake \& Liyanagama, 2012). Small-scale irrigation schemes are under the 


\section{Appendix References}

Azmi, F. (2007), Changing livelihoods among the second and third generations of settlers in System H of the Accelerated Mahaweli Development Project (AMDP) in Sri Lanka, Norsk Geografisk Tidsskrift - Norwegian Journal of Geography, 61(1), 1-12, doi:10.1080/00291950601173903

Biswas, S. \& M. Adank, (2004), Cost Recovery and Financing of Rural Water Supply in Bangladesh: A Case Study, Natural Resource Centre, NGO Forum for Drinking Water Supply and Sanitation, accessed online 21 May 2014 at <http://www.irc.nl/content/download/22110/258575/file/cost_recovery_and_financing.pdf $>$.

Chowdhury, N. T. (2010), Water management in Bangladesh: an analytical review, Water Policy, 12(1020): 32-51.

Gunatilaka, A. (2008), Water security and related issues in Sri Lanka: the need for integrated water resource management (IWRM), Journal of the National Science Foundation of Sri Lanka, 36 Special, 3-15.

Manthrithilake, H., \& B. S. Liyanagama (2012), Simulation model for participatory decision making: water allocation policy implementation in Sri Lanka, Water International, 37(4), 478-491. 
Marambe, B., G. Pushpakumara, \& P. Silva, (2012), Biodiversity and Agrobiodiversity in Sri Lanka: Village Tank Systems in The Biodiversity Observation Network in the Asia-Pacific Region: Toward Further Development of Monitoring, Ecological Research Monographs, Tokyo, Springer Japan, 479 pgs.

Thuraisingham, M. (2013), Interview with Mr. M. Thuraisingham, Additional Director General of Irrigation on 4 June 2013.

UNCTAD (United National Conference on Trade and Development) (2011), "The Least Developed Countries in 2011: The Potential Role of South-South Cooperation for Inclusive and Sustainable Development," accessed online 20 August 2013 at $\langle$ http://unctad.org/en/Docs/ldc2011_en.pdf $\rangle$.

World Bank (2013), "Bangladesh: Priorities for Agriculture and Rural Development," accessed online on 22 August 2013 at <http://web.worldbank.org/WBSITE/EXTERNAL/COUNTRIES/SOUTHASIAEXT/EXTS AREGTOPAGRI/0,,contentMDK:20273763 menuPK:548213 pagePK:34004173 piPK:34 003707 theSitePK:452766,00.html>. 


\section{References}

ADB (Asian Development Bank) (2013a), Asian Water Development Outlook 2013: Measuring Water Security in Asia and the Pacific, Asian Development Bank, Mandaluyong City, Philippines.

ADB, (2013b), "Key Development Indicators for Asia and the Pacific, Manila, Philippines," accessed online 23 August 2013 at <http://www.adb.org/publications/series/key-indicatorsfor-asia-and-the-pacific $>$.

ADB, (2013c), "Economic and Research Development: Basic Statistics 2013," spreadsheet accessed online 23 August 2013 at <http://www.adb.org/publications/basic-statistics-2013 >.

Appelgren, B. \& W. Klohn, (1999), Management of Water Scarcity: A Focus on Social Capacities and Options, Physics and Chemistry of the Earth, Part B: Hydrology, Oceans and Atmosphere, 24(4), 361-373.

Biswas, A. K. \& K.E. Seetharam (2008), Achieving Water Security for Asia, International Journal of Water Resources Development, 24, 145-176.

Brown, C. \& U. Lall (2006), Water and economic development: The role of variability and a framework for resilience, Natural Resources Forum, 30(4), 306-317, doi:10.1111/j.14778947.2006.00118.x.

Brown, A. \& M.D. Matlock. (2011), A Review of Water Scarcity Indices and Methodologies. Food, Beverage, and Agriculture: White Paper \#106. 21 pgs.

Chenoweth, J. (2008), A re-assessment of indicators of national scarcity, Water International, $33(1), 5-18$.

Cook, C. \& K. Bakker (2012), Water security: Debating an emerging paradigm, Global Environmental Change, 22, 94-102.

Falkenmark, M. (1989), "The massive water scarcity threatening Africa-why isn't it being addressed," Ambio, 18(2): 112-118.

FAO (Food and Agricultural Organization) (2007), Coping with water scarcity: challenge of the twenty-first century, accessed online 21 May 2014 at <http://www.fao.org/hr/water/docs/escarcity.pdf $>$.

FAO (2012), Irrigation in Southern and Eastern Asia in figures, AQUASTAT Survey - 2011, FAO Water Report \#37, accessed online 1 August 2013 at <http://www.fao.org/docrep/016/i2809e/i2809e.pdf $>$.

FAO (2013), AQUASTAT Database, accessed 1 May 2013 online at <http://www.fao.org/nr/water/aquastat/main/index.stm>.

Feitelson, E., \& J. Chenoweth, (2002), Water poverty: towards a meaningful indicator, Water Policy, 4 (3), 263-281.

Gain, A. K., C. Giupponi, \& F. G. Renaud (2012), Climate Change Adaptation and Vulnerability Assessment of Water Resources Systems in Developing Countries: A Generalized Framework and a Feasibility Study in Bangladesh, Water, 4(4), 345-366, doi:10.3390/w4020345.

Gleick, P.H. (2003), Global Freshwater Resources: Soft-Path Solutions for the 21st Century, Science, 302 (5650): 1524-1528.

Grey, D. \& C.W. Sadoff (2007), Sink or Swim? Water security for growth and development, Water Policy, 9, 545-571.

Hornberger, G.M., J.P. Raffensperger, P.L. Wiberg, \& K.N. Eshleman (1998), Elements of Physical Hydrology, Baltimore, MD: John Hopkins University Press, 302 pgs. 

Economies, Institute of Water Policy, Working Paper No.2/2009, 27 pgs.

Kaufmann, D. (2005), Myths and realities of governance and corruption, accessed online 1 July 2010 at $<$ http://mpra.ub.uni-muenchen.de/8089/1/Myths_Realities_Gov_Corruption.pdf $>$.

Kelly P.M. \& W.N. Adger (2000), Theory and practice in assessing vulnerability to climate change and facilitating adaptation, Clim Change, 47:325-352, doi:10.1023/A:1005627828199

Lautze, J. \& H. Manthrithilake (2012), Water security: Old concepts, new package, what value?, Natural Resources Forum, 36, 76-87.

Lawrence, P., J. Meigh, \& C. Sullivan (2002), The water poverty index: An international comparison, Keele Economics Research Papers, 2002/19, http://www.keele.ac.uk/depts/ec/cer/pubs_kerps.htm

Mawilmada, N., S. Atapattu, J. Dela, N. Gunawardene, B. Weerasinghe, M. Nandana, A. Bellanwawithana, R. Wimalasiri, \& N. Kumari (2010), "Sector Vulnerability Profile: Sri Lanka. Supplementary Document to: The National Climate Change Adaptation Strategy for Sri Lanka 2011 to 2016," accessed online on 29 July 2013 at <http://www.climatechange.lk/adaptation/Files/Water_SVP_Nov-16-2010.pdf $>$.

Molden, D. (Ed.) (2007), Water for food, water for life: A comprehensive assessment of water management in agriculture. London, UK: Earthscan, and Colombo, Sri Lanka: International Water Management Institute, 11 pgs.

Molle, F. \& P. Mollinga (2003), Water poverty indicators: conceptual problems and policy issues, Water Policy, 5 (5), 529-544.

Paladini, S. (2012), Evaluating Water Security in the Asia-Pacific Region: A New Approach Based on Vulnerability Indices, Eurasian Geography and Economics, 53(1), 95-114, doi:10.2747/1539-7216.53.1.95.

Penn, M.R., J.J. Pauer, \& J.R. Mihelcic (2006), "Water Quality: Biochemical Oxygen Demand," in Environmental and Ecological Chemistry, Vol 2, 452 pgs.

Plummer, R., R. Loë, \& D. Armitage (2012), A Systematic Review of Water Vulnerability Assessment Tools, Water Resources Management, 26(15), 4327-4346, doi:10.1007/s11269012-0147-5.

Raskin, P., P. Gleick, P. Kirshen, G. Pontius, \& K. Strzepek (1997), Water Futures: Assessment of Long-range Patterns and Prospects, Stockholm, Sweden: Stockholm Environment Institute.

Rijsberman, F.R. (2006), "Water scarcity: Fact or Fiction?" Agricultural Water Management, 80: 5-22.

Seckler, D., U. Amrasinghe, D. Molden, R. de Silva, \& R. Barker (1998), World water demand and supply, 1990 to 2025: Scenarios and Issues, Colombo: International Water Management Institute, Research Report \#19.

Senaratne, A. (1996), Use of groundwater to alleviate water deficit during dry season (yala) in the NCP of SL, A report submitted to the Sri Lanka National Program office of the IIMI, Battarmulla, SL.

Shah, T., A.D. Roy, A.S. Qureshi, \& J. Wang (2003), Sustaining Asia's groundwater boom: An overview of issues and evidence, Natural Resources Forum, 27(2), 130-141, doi:10.1111/1477-8947.00048.

Sullivan, C. (2002), Calculating a Water Poverty Index, World Development, 30(7): 1195-1210. 
Sullivan, C. \& J. Meigh (2003), Considering the water poverty index in the context of poverty alleviation, Water Policy, 5, 513-528.

Sullivan, C.A. J.R. Meigh, T. Giacomello, T. Fediw, P. Lawrence, \& M. Samad (2003), The water poverty index: Development and application at the community scale, Natural Resources Forum, 27, 189-199.

Sullivan C.A., A. Cohen, J.M. Faurès, \& G. Santini (2009), The rural water livelihoods index, Working paper. Food and Agricultural Organization of the United Nations, Rome, accessed online 5 May 2013 at <http://www.fao.org/nr/water/docs/FAOW_RWLI_paper.pdf $>$.

Sultana, F. (2007), Water, water everywhere, but not a drop to drink: Pani politics (water politics) in rural Bangladesh, International Feminist Journal of Politics, 9(4), 494-502. doi:10.1080/14616740701607994.

Transparency International (2013), “2012 Corruptions Perceptions Index,” accessed online 20 May 2013 at <http://cpi.transparency.org/cpi2012/>.

UN (United Nations) (2013a), "International Decade for Action 'Water for Life' 2005-2015," accessed online 10 August 2013 at <http://www.un.org/waterforlifedecade/scarcity.shtml $>$.

UN (2013b), Millennium Development Goals Indicators Database, accessed online 1 August 2013 at <http:// millenniumindicators.un.org/unsd/mdg/Data.aspx>.

UN-Water (2013), Water Security \& the Global Water Agenda: A UN-Water Analytical Brief, 47 pgs.

UNDP (United Nations Development Programme) (2006), Human Development Report 2006: Beyond scarcity: Power, poverty and the global water crisis, ISBN 0-230-50058-7, http://hdr.undp.org, 423pp.

UNDP (2013a), "Human Development Report 2013: The Rise of the South: Human Progress in a Diverse World," accessed online 2 August 2013 at <http://hdr.undp.org/en/reports/global/hdr2013/>.

UNDP (2013b), "Gender Inequality Index," accessed online 2 August 2013 at $<$ http://hdr.undp.org/en/statistics/gii/>.

Vaux, H. (2012), Water for agriculture and the environment: the ultimate trade-off, Water Policy, 14(S1), 136, doi:10.2166/wp.2012.209.

Villholth, K.G., \& L.D. Rajasooriyar (2010), Groundwater Resources and Management Challenges in Sri Lanka-an Overview, Water Resources Management, 24(8), 1489-1513, doi:10.1007/s11269-009-9510-6.

WHO (World Health Organization) \& UNICEF (2012), Progress on drinking water and sanitation, Joint Monitoring Programme update 2012, accessed online 1 December 2013 at <http://www.who.int/water_sanitation_health/publications/2012/jmp_report/en/index.html>.

World Bank (2013a), "Governance Indicators," accessed online 10 August 2013 at 〈http://info.worldbank.org/governance/wgi/mc_chart.asp >.

World Bank (2013b), "Gross National Income," accessed online 4 September 2013 at <http://data.worldbank.org/indicator/NY.GNP.PCAP.PP.CD>.

WRI (World Resources Institute) (2013), Aqueduct Water Risk Atlas, accessed online on 15 July 2013 at $<$ http://aqueduct.wri.org/atlas $>$.

YCELP (Yale Center for Environmental Law and Policy), \& CIESIN (Center for International Earth Science Information Network) of Columbia University (2005), 2005 Environmental Sustainability Index: Benchmarking National Environmental Stewardship. 414 pgs. 
Table 1: Bangladesh and Sri Lanka Country Profiles

\begin{tabular}{|l|l|l|l|}
\hline & \multicolumn{1}{|c|}{ Bangladesh } & \multicolumn{1}{|c|}{ Sri Lanka } & Source \\
\hline Land area $\left(\mathrm{km}^{2}\right)$ & 144,000 & 25,332 & FAO, 2012 \\
\hline Population $(\mathrm{x} 1000)$ & 150,494 & 21,025 & FAO, 2013 \\
\hline $\begin{array}{l}\text { Population density } \\
\left.\text { (inhabitants/km }{ }^{2}\right)\end{array}$ & 1,045 & 321 & FAO, 2013 \\
\hline Population growth rate $(\%)$ & 1.3 & 0.7 & ADB, 2013b \\
\hline Mean annual temperature $\left({ }^{\circ} \mathrm{C}\right)$ & $25^{\circ} \mathrm{C}$ & $\begin{array}{l}27^{\circ} \mathrm{C} \text { in the } \\
\text { lowlands, } 15^{\circ} \mathrm{C} \text { in } \\
\text { the central highlands }\end{array}$ & FAO, 2012 \\
\hline $\begin{array}{l}\text { Total cultivable land area } \\
\text { (hectares per capita) }\end{array}$ & 0.06 & 0.10 & FAO, 2013 \\
\hline $\begin{array}{l}\text { Gross domestic product, PPP } \\
\text { (\$US 2012 per capita) }\end{array}$ & 1,943 & 6,040 & ADB, 2013b \\
\hline
\end{tabular}


Table 2. Indices for Bangladesh and Sri Lanka

\begin{tabular}{|c|c|c|c|}
\hline Index & Bangladesh $^{\mathrm{a}}$ & Sri Lanka ${ }^{a}$ & Source \\
\hline Falkenmark Indicator & $\begin{array}{c}8,153 \\
\mathrm{~m}^{3} / \text { person/year } \\
\text { (No water stress) }\end{array}$ & $\begin{array}{c}2,509 \\
\mathrm{~m}^{3} / \text { person/year } \\
\text { (No water stress) }\end{array}$ & $\begin{array}{l}\text { Falkenmark, 1989; } \\
\text { Data: FAO, } 2013\end{array}$ \\
\hline $\begin{array}{c}\text { Social Water Scarcity } \\
\text { Index }\end{array}$ & $\begin{array}{l}2.4 \text { (relative } \\
\text { sufficiency) }\end{array}$ & $\begin{array}{l}5.6 \text { (relative } \\
\text { sufficiency) }\end{array}$ & $\begin{array}{l}\text { Appelgren \& Klohn, } \\
\text { 1999; Data: FAO, } \\
\text { 2013; UNDP, 2013a }\end{array}$ \\
\hline Water Poverty Index & 58.1 out of 100 & 58.5 out of 100 & $\begin{array}{l}\text { Lawrence, Meigh, \& } \\
\quad \text { Sullivan, } 2002\end{array}$ \\
\hline $\begin{array}{c}\text { Rural Water } \\
\text { Livelihoods Index }\end{array}$ & 65.44 out of 100 & 68.62 out of 100 & Sullivan et al., 2009 \\
\hline $\begin{array}{c}\text { Index of Drinking } \\
\text { Water Adequacy-2 }\end{array}$ & 24 out of 100 & 37 out of 100 & $\begin{array}{l}\text { Kallidaikurichi \& Rao, } \\
2009\end{array}$ \\
\hline $\begin{array}{c}\text { Water Resources } \\
\text { Vulnerability Index }\end{array}$ & 3 (Stress) & 4 (High stress) & Raskin et al., 1997 \\
\hline $\begin{array}{l}\text { Composite Water } \\
\text { Vulnerability Index }\end{array}$ & $\begin{array}{l}0.11 \text { (Low } \\
\text { resilience) }\end{array}$ & $\begin{array}{l}0.22 \text { (Upper-low } \\
\text { resilience) }\end{array}$ & Paladini, 2012 \\
\hline $\begin{array}{l}\text { National Water } \\
\text { Security Index }\end{array}$ & 1 out of 5 & 2 out of 5 & $\mathrm{ADB}, 2013 \mathrm{a}$ \\
\hline Water Security Index & 13.5 (Poor) & 15 (Satisfactory) & $\begin{array}{c}\text { Lautze \& } \\
\text { Manthrithilake, } 2012\end{array}$ \\
\hline
\end{tabular}

${ }^{\mathrm{a}}$ Shaded indices indicate country with a more favorable ranking. 
Table 3: Water Index Parameter Values for Bangladesh and Sri Lanka

\begin{tabular}{|c|c|c|c|c|c|c|c|}
\hline & \multicolumn{3}{|c|}{ Parameters } & Bangladesh $^{\mathrm{a}}$ & Sri Lanka ${ }^{a}$ & Source & $\begin{array}{l}\text { Indices using } \\
\text { parameters }\end{array}$ \\
\hline \multirow{7}{*}{ 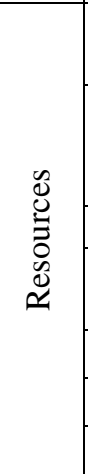 } & \multicolumn{3}{|c|}{$\begin{array}{l}\text { Total renewable water sources } \\
\left(\mathrm{m}^{3} / \text { person/year) }\right.\end{array}$} & 8,153 & 2,509 & FAO, 2013 & FI, SWSI, WPI, CWVI \\
\hline & \multicolumn{3}{|c|}{$\begin{array}{l}\text { Total renewable water sources } \\
\text { located within a nation's } \\
\text { boundaries }\left(\mathrm{m}^{3} / \text { person/year) }\right.\end{array}$} & 698 & 2,509 & FAO, 2013 & IDWA-2 \\
\hline & \multicolumn{3}{|c|}{ Dependence on external sources } & $91.4 \%$ & $0 \%$ & FAO, 2013 & WSI, WRVI \\
\hline & \multicolumn{3}{|c|}{$\begin{array}{l}\text { Inter-annual variability in } \\
\text { precipitation }\end{array}$} & 0.11 & 0.20 & $\begin{array}{l}\text { Raskin et al., } \\
1997\end{array}$ & WRVI, RWLI ${ }^{\mathrm{c}}$ \\
\hline & \multicolumn{3}{|c|}{ Flood Indicator } & 0.23 & 0.44 & ADB, 2013a & NWSI \\
\hline & \multicolumn{3}{|c|}{ Drought Indicator } & 0.13 & 0.51 & ADB, 2013a & NWSI \\
\hline & \multicolumn{3}{|c|}{ Coastal Indicator } & 0.20 & 0.44 & ADB, 2013a & NWSI \\
\hline \multirow{9}{*}{ 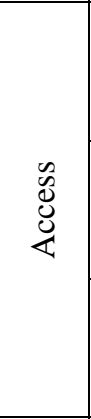 } & \multirow{3}{*}{\multicolumn{2}{|c|}{$\begin{array}{l}\text { Population with } \\
\text { access to } \\
\text { improved water }\end{array}$}} & Total & $83 \%$ & $93 \%$ & \multirow{3}{*}{ UN, 2013b } & WPI, CWVI, WSI \\
\hline & & & Urban & $85 \%$ & $99 \%$ & & \\
\hline & & & Rural & $82 \%$ & $92 \%$ & & RWLI \\
\hline & \multirow{3}{*}{\multicolumn{2}{|c|}{$\begin{array}{l}\text { Population with } \\
\text { household } \\
\text { connections }\end{array}$}} & Total & $6 \%$ & $29 \%$ & \multirow{3}{*}{$\begin{array}{l}\text { ADB, 2013b; } \\
\text { Kallidaikurichi } \\
\text { \& Rao, } 2009\end{array}$} & NWSI, IDWA-2 \\
\hline & & & Urban & $20 \%$ & $67 \%$ & & NWSI, IDWA-2 \\
\hline & & & Rural & $0.23 \%$ & $3.76 \%$ & & IDWA-2 \\
\hline & \multirow{3}{*}{\multicolumn{2}{|c|}{$\begin{array}{l}\text { Population with } \\
\text { access to } \\
\text { sanitation }\end{array}$}} & Total & $55 \%$ & $91 \%$ & \multirow{3}{*}{ UN, 2013b } & WPI, NWSI \\
\hline & & & Urban & $55 \%$ & $83 \%$ & & \\
\hline & & & Rural & $55 \%$ & $93 \%$ & & RWLI \\
\hline \multirow{5}{*}{ D } & \multirow{4}{*}{\multicolumn{2}{|c|}{$\begin{array}{l}\text { Water } \\
\text { withdrawals (\% } \\
\text { of total water } \\
\text { resources) }\end{array}$}} & Total & $2.9 \%$ & $24.5 \%$ & \multirow{4}{*}{ FAO, 2013} & WRVI, RWLI, CWVI \\
\hline & & & $\begin{array}{l}\text { Domestic/ } \\
\text { Municipal }\end{array}$ & $0.3 \%$ & $1.5 \%$ & & WPI, CWVI, IDWA-2 \\
\hline & & & Agricultural & $2.6 \%$ & $21.4 \%$ & & WPI, WSI \\
\hline & & & Industrial & $0.1 \%$ & $1.6 \%$ & & WPI, CWVI \\
\hline & \multicolumn{3}{|c|}{$\begin{array}{l}\text { Water Consumption (\% of land } \\
\text { area that exceeds } 40 \% \text { of total } \\
\text { available water) }\end{array}$} & $22.9 \%$ & $32.9 \%$ & $\begin{array}{l}\text { YCELP \& } \\
\text { CIESIN, } 2005\end{array}$ & WPI \\
\hline \multirow{8}{*}{ 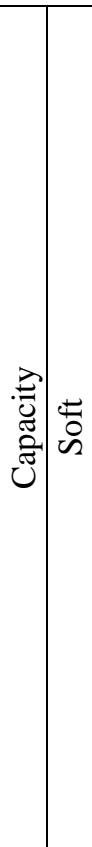 } & \multirow{3}{*}{ Education } & \multicolumn{2}{|c|}{$\begin{array}{l}\begin{array}{l}\text { Expected years of } \\
\text { schooling }^{\mathrm{d}}\end{array} \\
\end{array}$} & 12.7 & 8.1 & UNDP, 2013a & SWSI, CWVI \\
\hline & & \multicolumn{2}{|c|}{$\begin{array}{l}\text { Mean years of } \\
\text { schooling }^{\mathrm{d}}\end{array}$} & 4.8 & 9.3 & UNDP, 2013a & SWSI, CWVI \\
\hline & & \multicolumn{2}{|c|}{$\begin{array}{l}\text { Literacy rate }(\% \text { of } \\
\text { adults over } 15)\end{array}$} & $56.8 \%$ & $91.2 \%$ & ADB, 2013b & NWSI \\
\hline & \multirow{3}{*}{ Health } & \multicolumn{2}{|c|}{$\begin{array}{l}\text { Life expectancy at } \\
\text { birth (years) }\end{array}$} & 69.2 & 75.1 & UNDP, 2013a & SWSI, CWVI \\
\hline & & \multicolumn{2}{|c|}{$\begin{array}{l}\text { Child mortality } \\
\text { (under } 5 \text { years) (per } \\
1000 \text { births) }\end{array}$} & 59 & 12 & ADB, 2013b & WPI \\
\hline & & \multicolumn{2}{|c|}{$\begin{array}{l}\text { Percentage of } \\
\text { undernourished } \\
\text { people }\end{array}$} & 17 & 24 & ADB, 2013b & RWLI \\
\hline & \multirow{2}{*}{$\begin{array}{l}\text { Income: } \\
\text { GNI per } \\
\text { capita }\end{array}$} & $\begin{array}{l}\text { GN } \\
(20 \\
\text { Inte }\end{array}$ & $\begin{array}{l}\text { per capita, PPP } \\
3 \$ \\
\text { (national) } \\
\text { d }\end{array}$ & 2,070 & 6,120 & $\begin{array}{l}\text { World Bank, } \\
2013 b\end{array}$ & SWSI, CWVI \\
\hline & & $\begin{array}{l}\text { GD } \\
\text { pur } \\
\text { par }\end{array}$ & $\begin{array}{l}\text { per capita at } \\
\text { hasing power } \\
\text { ty (\$US 2012) }\end{array}$ & 1,917 & 6,247 & ADB, 2013b & $\begin{array}{l}\text { WPI, IDWA-2, WRVI, } \\
\text { CWVI }\end{array}$ \\
\hline
\end{tabular}




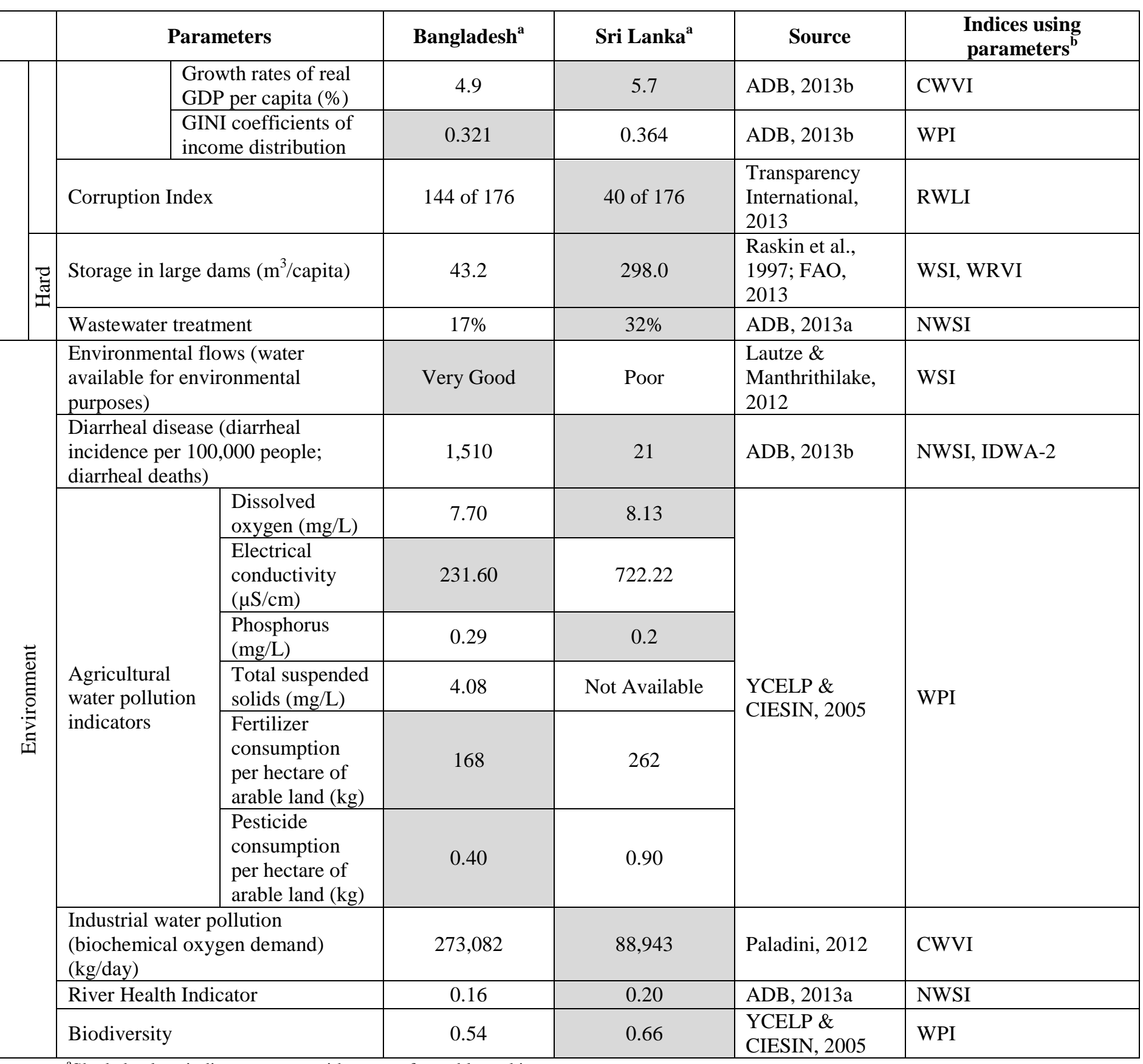

${ }^{\text {a}}$ Shaded values indicate country with a more favorable ranking.

${ }^{\mathrm{b}}$ FI: Falkenmark Indicator, SWSI: Social Water Scarcity Index, WPI: Water Poverty Index, RWLI: Rural Water Livelihoods Index, IDWA-2: Index of Drinking Water Adequacy-2, NWSI: National Water Security Index, WSI: Water Security Index, WRVI: Water Resources Vulnerability Index, and CWVI: Composite Water Vulnerability Index.

${ }^{c}$ RWLI uses inter-annual variation in cattle holdings and cereal production as a proxy for the coefficient of variation in precipitation.

${ }^{\mathrm{d}}$ Some indices use the Human Development Index, which is composite of these parameters. HDI represents three dimensions of human development: a long life, as measured by life expectancy at birth; access to knowledge, as measured by mean years of adult education; and standard of living, as measured by gross national income per capita, expressed in a constant purchasing power parity, PPP (2012\$). The current HDI for Bangladesh and Sri Lanka are 0.515 and 0.715 respectively (UNDP, 2013a). 
4

5

6

7

8

9

\section{Table 4: Missing Parameters}

\begin{tabular}{|c|c|c|c|c|}
\hline & Parameters & Bangladesh $^{\mathrm{a}}$ & Sri Lanka $^{a}$ & Source \\
\hline \multirow{2}{*}{ 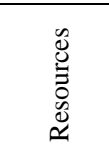 } & Groundwater resources ( $\mathrm{m}^{3} /$ person/year) & 140 & 371 & FAO, 2013 \\
\hline & Intra-annual variability in precipitation & High & Low-medium & WRI, 2013 \\
\hline 岕 & Gender inequality index & 0.508 & 0.402 & UNDP, 2013b \\
\hline \multirow{2}{*}{$\stackrel{0}{0}$} & $\begin{array}{l}\text { Groundwater withdrawal (\% of total } \\
\text { resources) }\end{array}$ & $79.4 \%$ & Not Available & FAO, 2013 \\
\hline & $\begin{array}{l}\text { Water consumption (\% of groundwater } \\
\text { resources) }\end{array}$ & Not Available & Not Available & \\
\hline \multirow{6}{*}{ 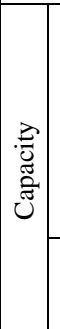 } & Voice and accountability (percentile rank) & 34.1 & 29.9 & World Bank, 2013a \\
\hline & Political stability (percentile rank) & 9.0 & 22.7 & World Bank, 2013a \\
\hline & Government effectiveness (percentile rank) & 22.5 & 45.9 & World Bank, 2013a \\
\hline & Regulatory quality (percentile rank) & 19.6 & 48.3 & World Bank, 2013a \\
\hline & Rule of laws (percentile rank) & 19.4 & 52.1 & World Bank, 2013a \\
\hline & $\begin{array}{l}\text { Small-scale irrigation schemes ( } \% \text { of } \\
\text { surface water coverage) }\end{array}$ & $16 \%$ & $25 \%$ & $\begin{array}{l}\text { Mawilmada et al., } \\
\text { 2010; FAO, } 2012\end{array}$ \\
\hline \multirow{5}{*}{ 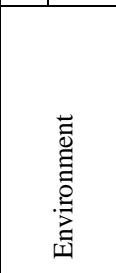 } & Toxic metal pollution & Not Available & Not Available & \\
\hline & Fecal coliforms & Not Available & Not Available & \\
\hline & $\begin{array}{l}\text { Percentage of coastal resources affected by } \\
\text { salinization }\end{array}$ & Not Available & Not Available & \\
\hline & Percentage of natural vegetation land cover & $11.1 \%$ & $28.8 \%$ & $\mathrm{ADB}, 2013 \mathrm{c}$ \\
\hline & Deforestation rate & $0.18 \%$ & $0.78 \%$ & ADB, 2013b \\
\hline
\end{tabular}

${ }^{\mathrm{a}}$ Shaded values indicate country with a more favorable ranking.

${ }^{\mathrm{b}}$ Due to lack of data, surface area instead of volume of water stored in small-scale irrigation schemes is listed. 